\title{
Climate Change and Ecocide in Sierra Leone: Representations in Aminatta Forna's Ancestor Stones and The Memory of Love
}

\author{
Shruti Das \\ (D) https://orcid.org/0000-0002-6148-1093 \\ Berhampur University, Odisha, India \\ Deepshikha Routray \\ (1) https://orcid.org/0000-0003-4517-9449 \\ Maharishi College of Natural Law, Odisha, India
}

\begin{abstract}
War has been instrumental in destroying land and forests and thus is a major contributor to climate change. Degradation due to war has been especially significant in Africa. The African continent, once green, is now almost denuded of its rich forests and pillaged of its precious natural resources due to the brutality of colonisation and more recent postcolonial civil wars. In Sierra Leone the civil war continued for over eleven years from 1991 to 2002 and wrought havoc on the land and forests. Thus the anxiety and trauma suffered by the people not only includes the more visible aspects of human brutality, but also the long lasting effects of ecocide which relate to climate change. Underlying narratives that address traumatic ecological disasters is a sense of anxiety and depression resulting from the existential threat of climate change. This paper demonstrates how narratives can metaphorically represent both ecocide and climate change and argues that such stories help people in tackling the real life stresses of anxiety and trauma. To establish the argument this paper has drawn on scientific and sociological data and placed these vis-à-vis narrative episodes in Aminatta Forna's novels Ancestor Stones (2006) and The Memory of Love (2010). In these novels Forna depicts the ecological crisis that colonisation and civil war have wrought on Sierra Leone. The anxiety and post-traumatic stress disorder of war and ecocide - suffered by the fictional Sierra Leonean characters are explained through Cathy Caruth's trauma theory.
\end{abstract}

Keywords: Sierra Leone, civil war, ecocide, eco-anxiety, climate trauma, climate change, narrative fiction, Aminatta Forna

eTropic: electronic journal of studies in the tropics publishes new research from arts, humanities, social sciences and allied fields on the variety and interrelatedness of nature, culture, and society in the tropics. Published by James Cook University, a leading research institution on critical issues facing the world's Tropics. Free open access, Scopus Listed, Scimago Q1. Indexed in: Google Scholar, DOAJ, Crossref, Ulrich's, SHERPA/RoMEO, Pandora. ISSN 1448-2940. Creative Commons CC BY 4.0 free to download, save and reproduce. To cite, include: Author(s), Title of Paper, Editors (Eds.) Special Issue Title (Special Issue) eTropic, volume, issue, year, pages and DOI: http://dx.doi.org/10.25120/etropic.20.2.2021.3812 
eTropic 20.2 (2021) Special Issue: Tropical Imaginaries and Climate Crisis

\section{Storying Climate Change in Sierra Leone}

I n October 2009, a few months before the Copenhagen UN Climate Change Conference (COP15), President Mohamed Nasheed of the archipelago nation of the Maldives, convened an urgent underwater cabinet meeting. The cabinet signed a petition requesting nations to lower their carbon-dioxide emissions. The dramatic signing was intended to alert the world to the imminent environmental dangers of greenhouse gases which contribute to climate change effects, including and of particular concern to the Maldives - rising sea levels. This year, in November 2021 the UK and Italy will co-host the $26^{\text {th }}$ UN Climate Change Conference (COP26). One of the goals of the meeting is to persuade all countries to work towards reducing net emissions of anthropogenic greenhouse gases to zero by 2050 . Discussions will include the urgent curtailment of extractive industries and deforestation both of which destroy ecologies across vast regions and are root causes of climate change. Given the interconnectivity between ecologies and climate change, massive land degradation and deforestation becomes a form of ecocide, and the resulting climate change, although intangible, significantly impacts human life and induces anxiety.

As Una Chaudhury and Shonni Enelow explain in their article "Theorizing Ecocide: The Theatre of Eco-Cruelty":

The first thing that makes climate change difficult to represent in art is the maddening fact that climate-unlike weather-can never be directly experienced. As the aggregation of numerous atmospheric and weather phenomena, climate does not manifest itself in any single moment, event, or location. The only way it can be apprehended is through data and modeling - through systems and mediations-all of which have to be processed cognitively and intellectually: have to, in short, be understood, rather than experienced, phenomenologically and temporally. (2014, p. 23)

This paper proposes to analyze how the complex process of climate change in Sierra Leone has been processed cognitively and intellectually through storytelling representation in Aminatta Forna's novels Ancestor Stones (2006) and The Memory of Love (2010). However, climate change representation is never simple or straightforward. As Susan E. Babbit in "Stories from the South: A Question of Logic" reminds us, stories are about something other than what initially appears to the reader. They are not explicit representations, but rather, answer or problematize important issues. Hence Babbit suggests "that stories themselves are not as epistemically significant as the questions that determine their meaningfulness in a specific context" 
eTropic 20.2 (2021) Special Issue: Tropical Imaginaries and Climate Crisis

(2005, p.2). This meaningful context, in the novels of Forna, includes war induced ecological destruction in Sierra Leone. Babbit's thesis can be furthered through the arguments of both Timothy Clark and Maggie Kainulainen. Clark notes "that a story gains its power from material that the writer...chooses to exclude, such that its absence determines the contours of the text that readers actually follow" (2019, p.162). Here we are interested in how Forna's two novels have as a backdrop ecological trauma, as if this is the absence within which the characters live. Maggie Kainulainen in "Saying Climate Change: Ethics of the Sublime and the Problem of Representation" addresses the social imaginary - and in this case, the tropical imaginary. She notes that along with the climate crisis there is a crisis of representation, for how can we "bear witness to the deep interconnection and undecidability that climate change reveals"? As she contends, climate change "exceeds boundaries by forcing us to think of a time beyond the human scale....and poses a direct and terrible threat". On the importance of representations of climate change in narratives, she contends: "because climate change as a totality can only be encountered through discourse, the issue of representation is key" (2013, p.111).

The objective of this paper is to analyse how Forna's stories of personal trauma, as depicted through characters in the two novels, direct the reader to the significant issue of climate change due to the severe impact of mining and deforestation in Sierra Leone beginning with colonialism, but especially felt during the postcolonial period of the nation's civil wars. The paper pays particular attention to how the trauma of ecocide is depicted through various representations within these narratives.

\section{Ecocide: Impact of the Civil War on the Environment}

The United Nations Environment Programme (UNEP) technical report Sierra Leone, Environment, Conflict and Peacebuilding Assessment (February 2010) stated that this small West-African nation had an "abundance of natural resources and environmental assets. From tropical forests to impressive coastlines, from mineral resources to fisheries, the environmental has long been the backbone of economic development" (p. 7). However, since the country's independence from British colonial rule in 1961, it has experienced five coups, an authoritarian single-party rule, and a civil war that lasted eleven years.

Inequitable benefits-sharing of natural resource wealth played a role in the impetus of the Sierra Leone civil war that ravaged the country from 1991 to 2002. Diamonds and other natural resources were used to fund combatants, and also became spoils of war. In the post-conflict era, the environmental impacts of the conflict and continued unsustainable natural resource management have presented 
eTropic 20.2 (2021) Special Issue: Tropical Imaginaries and Climate Crisis

challenges to development and peace consolidation that persist today. (p.11).

Sierra Leone's civil war brought environmental destruction in its wake. The longdrawn-out war and a weakened economy resulted in extensive mining (for blood diamonds), deforestation, land fragmentation, and loss of soil fertility. Deforestation led to the loss of rich biodiversity with an alarming rise in pollution levels. This kind of eco-violence happens in increments and thus goes largely unseen. It is a slow violence, akin to slow poisoning. As they lack immediacy the signs of destruction are not obvious and thus such casualties of nature are often ignored by people and Governments.

It is important to understand that just as warfare can lead to genocide it also leads to ecocide or mass destruction of the environment and extensive destruction of ecosystems. Environments, throughout history, have been silent victims to the largescale destruction caused by human agency, especially during times of war. Armies and rebel forces burn down forests and habitats to kill people hiding there. There are many examples throughout history as well as in recent memory where crimes against ecology have accelerated the Anthropocene. Arthur Galston, an American biologist first named mass destruction of ecosystems 'ecocide' in 1970 at a conference in Washington DC. At the time, Galston's concept of ecocide provided a powerful conceptual tool in criticizing the use of the chemical agents Napalm and Agent Orange to destroy South Vietnamese forests. Later Galston's idea of ecocide gained wider currency and addressed the harm being done to natural environments that eventually affect animals and humans (Hay, 2013). Ecocide is committed largely during international wars and long-drawn-out civil wars. This was particularly the case in Sierra Leone which was rich in diamonds and natural resources. The rebels wanted diamonds to fund the conflict, so they destroyed large areas of forests and dug up the land to extract the gems, thereby inducing ecological devastation.

It is pertinent to note that the traditional models of trauma theory do not adequately address the trauma resulting from large-scale ecological devastation and climate change. Health hazards faced by humans and animals due to climate change have been invariably addressed as a physiological and tangible reality but the connection to the psychological response of people has been largely neglected. In the case of climate change especially, people, unable to address the exact issue, adopt a psychosocial defense mechanism - mostly evading it. 
eTropic 20.2 (2021) Special Issue: Tropical Imaginaries and Climate Crisis

\section{Ecocide and Trauma in Ancestor Stones and The Memory of Love}

Aminatta Forna's narratives are representations of such trauma in the wake of the civil war in Sierra Leone. In The Memory of Love (2010) Forna covertly depicts deforestation, changes in agricultural produce (cannabis instead of the staple foods of cassava and rice), and the severe impact on the personal health of the people. In Ancestor Stones (2006) she offers a critique of the impact of diamond mining, degradation of the environment, the attachment of people, especially women, to the land and its traditions - and the resultant trauma of disconnection. Although Forna explicitly narrates the psychological impact of war, she underplays 'pretrauma', a term coined by E. Ann Kaplan in her book Climate Trauma (2016) to signify the traumatic imagining of future catastrophe. Our intention in this essay is to explicitly analyse the narratives from the perspective of climate trauma and give an ethical dimension to the narratives that can help readers to visualise the potential traumatic futures of the characters in a post-conflict scenario. Our interpretations differ from previous intellectual understandings of Forna's novels, which have mostly been analysed from feminist and race perspectives, in that we focus on the intangible climate trauma amidst the lived experience of the characters in war-torn Sierra Leone.

Forna's narratives offer a disturbing account of the ecological impact of war. They show how people willfully engage in the destruction of the environment. Forna's Ancestor Stones and The Memory of Love can be read as narratives presenting human destruction of the environment at the site of war and the inevitable disintegration of ecological stability. Ancestor Stones narrated from the point of view of four women living in Rofathane, a fictional place in Sierra Leone, gives a graphic description of pretrauma in the shape of human trafficking and torture inflicted by the rebels on the people along with the destruction of habitat. White businessmen fanned the conflict and surreptitiously engaged the rebels in mining gold and diamonds. The rebels forced the people to work for them in mines and even smuggled them out of the country. We read: "A band of miners were marched away from their workplace and not sighted until months later when they appeared on the other side of the country" (2006, p. 283). The harrowing tale continues:

They see the plastic containers, smell the petrol as it is splashed on the walls and roof of the store. Men with guns encircle the building. Those inside begin to shout and hammer at the door, frantic now.... They scramble over one another to escape the stifling fume-filled air and the certainty of death.... The screams of men as they burned must have been terrible, must have filled the air, sent the birds and animals fleeing. And yet nobody hears them. The killers were deaf to them ... We moved around the corpses, who stared up at us through melted 
eTropic 20.2 (2021) Special Issue: Tropical Imaginaries and Climate Crisis

eyes, reached out to us with charred and twisted limbs. (2006, pp. 290-91).

In regard to ecocide we read about trees being cut down, land dug up and river beds destroyed. The narrative leads us to the stories of two native women, Abie and Hawa. Abie returns from England to take possession of her ancestral coffee plantation and is shocked to find that it is no longer yielding as the entire area has been dug up to mine diamonds. Abie's lament, "All these had once been great avenues of trees" (2006, p. 10 ), is a pointer to the aridity of Africa after the plundering of resources, first by the colonisers, and later by the beneficiaries of the civil war. Hawa's story exposes us to the operation of a European mine owner, Mr Blue, whose only concern is profitable and secretive extraction of resources at heavy costs to the environment and the water table. Hawa and her friends, who were employed to carry water from the river to a factory, wonder why it needs enormous amounts of water. They hide behind a boulder and witness Mr Blue's ecocidal activities: "The white men stood on the shelf of the river bank and watched the men from the village digging, loading pans with gravel and rocks which other men carried on their heads and dumped into wooden boxes running with water. That was where all the water was going" (2006, p.147). The evidence of ecocide continues as the narrative tells us that in various places the white miners "were digging out of the river and up from the former rice fields" (2006, p.159).

This fictional representation directly relates to what the UNEP reported in 2010:

The mining sites that were expanded were not rehabilitated in any way, leaving effluent, degraded sites and lost arable land. The mining also caused a great deal of persistent damage to the sector, in terms of reduced flows of natural capital and a heavily degraded environment.... The extraction of natural resources played a very important role in wartime economic activity, as was widely reported. While the focus has traditionally been on the diamond sector - as it directly fuelled the civil conflict itself - instability forced other types of extraction, such as gold, timber and non-timber forest products, and quarrying, to replace more sustainable income opportunities. Because natural resources can be quickly and easily exploited for sale, without long lag times or much in the way of capital investment, this unsustainable, but rapid, natural capital extraction was prevalent during the conflict years. (UNEP, 2010, pp.45-9)

In this context, it is pertinent to recall Greta Gaard and Lori Gruen's observation in their essay "Ecofeminism: Toward Global Justice and Planetary Health" (1993) that, "Forests are dynamic ecosystems, home to insects and animals alike, producers of 
eTropic 20.2 (2021) Special Issue: Tropical Imaginaries and Climate Crisis

fresh air and water when left unharmed by humans.... Forests are intricately connected with human survival, as they supply the majority of the people with food and fuel" ( $p$. 2-3). Thus, the anxiety of the women in Ancestor Stones is inherently linked to ecocide as a consequence of the civil war.

In The Memory of Love, the narrative is centred around the stories of three men: Elias Cole, a retired academic from a university of Sierra Leone; Adrian Lockheart, a psychologist from England; and Kai Manasray, a talented local surgeon. They are surrounded by victims as well as perpetrators of violence as they face the lingering consequences of war. In the opening chapter, there is a sense of pervasive yet intangible loss. Elias Cole says he heard a song of loss and suffering that makes him cry. In the song, a young man longed for a time past, a time he had only heard about in the words of those who'd lived it, a time of hope and dreams. He was singing of the life lost to him because it had been his misfortune to be born much later when the world was already a different place $(2010$, p. 2). The agonised lyrics are the song of every Sierra Leonean craving for what was and will never be again. In another instance, Adrian's encounter with patients in a Freetown asylum where they are dazed, chained, and tied to beds brings home the painful reality of the impact of the civil war on the lives of people. These cannabis addicts have become mentally deranged and are brought to the hospital by their families, who disown them. The place is full of stench and the odour of the drug. "The smell hits him and clots in the back of his throat - fermented and feral, the smell of hiding places and of stale fear" $(2010$, p. 78). He is told that the patients often have hallucinations like people suffering from malaria. "Though families usually recognise the symptoms for themselves. Then we'll check for all the rest, starting with drug abuse. ... we can give him some haloperidol to keep him quiet" (2010, p. 82). He learns that "They keep the patients drugged. Drugged and chained" (2010, p. 84). Ileana, a psychiatrist in the hospital, talks about the condition of patients with Adrian. She refers to the acute substance abuse that was prevalent in Sierra Leone and how "it was encouraged among the new recruits [of the civil war]. They call it Booster Morale" (2010, p. 84). Here one can relate to Morten Boas' article on "Alcohol and Drugs in Post-War Sierra Leone" (2008), which states that "Alcohol and drugs played a part in the war as rebels, militia members and soldiers consumed it not only to boost their morale, but also as a tranquiliser to cope with the consequences of the human rights abuses that they committed" (p. 41).

The rebels involved in armed conflict, the doctors, and the victims of civil war, all used drugs. The rebels took drugs to become agents of violence and engage in random killings at the behest of their leaders; doctors used cannabis locally for the treatment of trauma; and the victims of the civil war took drugs to deal with their anxiety. A Reuters report of 2010 states that a majority of the local people are addicted to cannabis and that it has become a concern for Sierra Leone that people are mostly 
eTropic 20.2 (2021) Special Issue: Tropical Imaginaries and Climate Crisis

cultivating cannabis rather than their staple foods of cassava and rice (Johnson, 2010, para. 2). Thus cannabis was readily available at a cheap price and was used by the populace as well as in the prolonged treatment of trauma. This extensive use was without consideration of the ecological hazards its propagation wrought. Forna hints of these hazards in her narrative. Adrian Lockhart's enquiry about the preferred drug for the treatment of patients in the mental hospital results in the answer: "Cannabis mostly. There isn't much else anyone can afford. There is a bit of heroin. Brown brown, it's called here. But that's a lot more expensive, obviously, and has to come in from elsewhere" (2010, p.84). lan Wong, Jacob Brenner, and Van Butsic in their article "Cannabis an Emerging Agricultural crop, leads to Deforestation" published in Frontiers in Ecology and the Environment (2017) noted that excessive plantation of cannabis creates substantial threats to the surrounding environment. Taking up this argument, Ithaca College in its Science News on 31 October 2017, corroborated that "Planting cannabis for commercial production in remote locations is creating forest fragmentation, stream modification, soil erosion and landslides". In another study, "The Environmental Downside of Cannabis Cultivation", Jodi Helmer states that in the growing stage a cannabis plant requires 22 litres of water per day (2019, para. 6). Again, in a recent article "Cannabis and the Environment: What Science Tells Us and What We Still Need to Know" (2021), Wartenberg and co-authors clearly state that:

Although the total land-use footprint of cannabis cultivation is small compared to other agricultural crops, outdoor cultivation sites tend to disproportionally be located in remote and ecologically sensitive areas; this can lead to habitat loss and increased wildlife exposure to chemical, noise, air or light pollution.

In semi-arid, drought-prone regions, cannabis' water-use footprint can contribute to groundwater and streamflow depletion. In urban areas, compounds from human cannabis consumption persist in treated wastewater and could contribute to downstream contamination of aquatic ecosystems. (Wartenberg et al., 2021)

An article published in Nature Sustainability in the same year, goes further and states that cannabis is a climate gas. Researchers, it notes, "found that the energy required to yield one kilogram of dried cannabis flower produces the equivalent of 2-5 tonnes of carbon dioxide" (Summers et al. 2021, para. 3).

The stories in Forna's novels are fictional representations of such scientific opinion that show how people in Africa were involved in ecocide by implicating themselves in extractive mining and cannabis cultivation. Freetown, Sierra Leone's capital city, once rich in mineral resources has been denuded by the Government and the rebels, who 
eTropic 20.2 (2021) Special Issue: Tropical Imaginaries and Climate Crisis

mined excessively for diamonds and turned arable land to cannabis plantations. The local inhabitants, beset with poverty and crime, suffer from post-traumatic stress disorder. Stories of the lives of men and women: Elias, Adrian, Kai, and Abie, Hawa and other female characters, serve to foreground the anxiety of existence. The stories subtly expose the exploitation of nature and people - especially women - both during and after the civil war. The repressed trauma and the associated stress disorder depicted through scenes of ecocide in the narratives serve to enlarge our understanding of the eco-anxiety represented in the novels. A parallel can be drawn between Sierra Leone and war-ravaged Vietnam where ecocide was performed by defoliation and bombing that caused environmental devastation and trauma. ${ }^{1}$ Scientists have denounced the environmental destruction and potential human health catastrophe arising from the herbicidal warfare program infamously known as Operation Ranch Hand (Zierler, 2011, p.14). The history of wars has exhibited human control over water, land, forests and human resources. It has always been the prime motive of war, which itself explains the interconnectedness of war and environmental destruction. The World Atlas of Illicit Flows compiled by INTERPOL shows that: "The illicit exploitation of natural/environmental resources is estimated at 38 percent share of illicit flows to armed groups in conflict. When incomes from these natural resources are combined with their illicit taxation and extortion (26 percent) by the same non-state armed groups, the figure becomes as high as 64 percent" (Bielby, 2021). These statistics highlight the relationship between war and natural resources. The gradual climatic change that follows war and its environmental destruction leads to the depletion of natural resources required for human survival and results in a sociopsychological condition that can be called climate trauma.

The magnitude of landscape disturbance in a short period due to war is huge. And here it is important to note that the anthropogenic change resulting from wars didn't start with the use of modern warfare. Ancient armies also practiced various methods of environmental disturbance in order to combat their enemies. Joseph P. Hupy in his article "The Environmental Footprint of War" (2008), describes how the Roman barbaric tribes indulged in massive forest fires to burn their enemies; while the Roman army practised various forms of deliberate environmental disturbance like cutting off an army from a water supply: "they redirected streams or destroyed dams leading to catastrophic disturbances with the sole motive of wiping out the rival armies" (p. 408). The climate crisis that Africa, and in the case presented here, Sierra Leone, faces is a result of the plunder of its resources first by white colonisers and later by the perpetrators of the country's civil wars.

\footnotetext{
1 Similar to our argument here regarding trauma, John Armstrong (2019) in his work on Vietnamese-authored war narratives of the American War (as it is called in Vietnam) points to the importance of trauma narrative. His argument differs from the one presented here in that rather than evoking ecology, he invokes the Gothic.
} 
eTropic 20.2 (2021) Special Issue: Tropical Imaginaries and Climate Crisis

For a better understanding of the representations of war and its environmental devastation in the works of Aminatta Forna, it is pertinent to understand the geopolitical scenario of West Africa which forms the setting of her novels. A report presented by the government of Sierra Leone at the Third United Nations Conference on Least Developed Countries (2001), stated that many skilled people had left in order to avoid facing a jeopardised future in a country torn by civil war, and where it was extremely difficult to reconstruct the destroyed social and environmental infrastructure - which not only suffered massive destruction during wartime, but was followed by continuous plundering of the land due to mining. Here it is important to note that before the civil war in 1991, 40 percent of the people in Sierra Leone had access to safe drinking water which drastically deteriorated to 5 percent in the mid-2000s. Furthermore, there was a large-scale debilitating effect of war on basic sanitation, housing, schooling, and telecommunications etc. This extensive destruction of the social and natural environment finds poignant expression in both Ancestor Stones and The Memory of Love.

In Ancestor Stones Forna posits a rich and abundantly green Sierra Leone vis-à-vis a denuded one. A country which had orchards and plantations - "succulent mangoes, bursts of starfruit, avocadoes the size of man's head... sweet potatoes and yams peeped from earth, and great hands of bananas reached out to them" $(2006$, p. 6) - is reduced to ruined groves as both the colonisers and the rebels mine them for diamonds. The narrative moves through metaphors which allude to the trauma suffered. Asana, one of the women in the story, refers to the moon shadow man who imprisoned birds in cages. Caging the beautiful sunbird and doves serves as an allegory for trapping and caging all that was beautiful in Africa. Additionally, Asana's depiction of the moon shadow man as someone whose "massive feet crushed the foliage beneath them" $(2006$, p. 25) can be read as the destruction of natural resources due to colonisation which pains the African immensely, but is not overtly expressed. These narrative representations of the psychological condition of the Sierra Leonean characters can be better understood with reference to Cathy Caruth's theory of trauma which sheds light on the metaphorical representation of inexpressible trauma:

... not as the story of the individual in relation to the events of his own past, but as the story of the way in which one's own trauma is tied up with the trauma of another, the way in which trauma may lead, therefore, to the encounter with another, through the very possibility and surprise of listening to another's wound. (1996, p. 8)

Hence the "theory of trauma is written not only about but in the midst of trauma" (1996, p.8). In Ancestor Stones Forna contends, "That was the way it was with this country. Those who noticed refused to speak of it, as though they feared that to do so would 
eTropic 20.2 (2021) Special Issue: Tropical Imaginaries and Climate Crisis

make it real" (2006, p. 223). Such apprehension and anxiety translate into a state of trauma. Pramod Nayar, a literary critic, refers to this condition as 'ecoprecarity' - "the precarious lives humans lead in the event of ecological disaster" (Nayar, 2019, p.7). In The Memory of Love Forna describes how the state of Sierra Leone underplayed the destruction of the environment in the peacebuilding process. We read that people "are blotting out what happened, fiddling with the truth, creating their own version of events to fill in the blanks. A version of the truth which puts them in a good light, that wipes out whatever they failed to do and makes certain that none of them will be blamed" (2010, p. 351). Forna's narratives not only subtly foreground the ecological damage done to Africa but also point to the manner in which the existing ecosystems face the threat of invasion and resultant transformation due to lack of political will and willful public amnesia.

Likewise of note in Forna's narratives is her subtle critique of the loss of the connectedness people had with the land as a result of emulating the ways of the white masters and imbibing a Western culture of greed and ruthlessness. Ancestor Stones tells the story of how female ancestors handed down certain stones to their daughters who would communicate their feelings to these stones and tell them about everyday matters. The stones, believed to have a life of their own, are a symbol of the age-old symbiotic relationship between the people of Sierra Leone, the land and nature. Hence the loss of stones (diamonds) from the land disturbs their mental balance, for they believed in the ancient myth that

After heaven and earth Kuru made people. He called his angel and told him to separate the people into black and white. The angel did so. Then Kuru told the angel to bring all sorts of tools. When these were gathered in a pile in front of him, Kuru gave to the black people the plough, the hoe, the hammer and the anvil. And he sent them to live in the hills and the forests to be farmers and blacksmiths. They hoed the land and planted crops, and built themselves houses from earth and thatched them with palm leaves. To the white people he gave a compass, a ruler and a sextant. They built ships and sailed the seas. They traded and grew wealthy. Then Kuru saw that he had divided the gifts unfairly. So he gave the black people something that nobody else had. He gave them the power of divination. (2006, p. 143)

The stones symbolized the close association of women with their female ancestors through objects of nature. Dissociation of the women from the stones in the narrative, and their resultant trauma, can be read as an allegory of Sierra Leone being stripped of its natural resources due to continuous and random mining by the whites and the rebels and the helplessness of the people. Forna makes events pertaining to ecocide 
eTropic 20.2 (2021) Special Issue: Tropical Imaginaries and Climate Crisis

and ethnocide run parallel. Her fictional representation is a pointer to the facts presented by the UNEP in their report Africa: Atlas of Our Changing Environment (2008) where they observe that productivity of about $65 \%$ of the continent's agricultural lands has declined due to mining and pollution over the past 50 years, and over $30 \%$ of Africa's pastoral land and almost $20 \%$ of all forests and woodlands are classified as moderately or heavily degraded. The deforestation rate in Africa is twice the average of the rest of the world with more than four million hectares of primary forest disappearing every year.

The chaos during the presidential elections in 1996 and the ensuing civil war in Sierra Leone form the milieu of Forna's narrative in Ancestor Stones where we find expressive images of a "sky choked with dust. The city stank. Hope had shrivelled and crumbled away" (2006, p. 271). The trauma emanating from dissociation with nature is synonymous with the country's state of affairs following the rampant ecocide as a result of eleven years of civil war. The individual stories of the women in Ancestor Stones are glaring testimonies. Mariama, one of the female characters observes towards the end of the novel:

Something happened here. A change. Stealthy, creeping, slow. Like the way the desert is gradually covering the plain, one grain of sand at a time. It took place without us even noticing, so that the moment when we might have resisted passed unremarked. Suddenly it was irreversible. The evil had been let loose. But it was no longer among us, it was within. Everybody became part of it. In the city the animals grew fat while the humans starved. (2006, p.307)

The stealthy creeping change evoked in this passage can be understood through Rob Nixon's concept of 'Slow Violence'. In his book, Slow Violence and the Environmentalism of the Poor (2011) Nixon speaks of the changes that take place, unnoticed, as destructive forces remain unchecked over a long time. Here it is pertinent to note that it was slowly, years after the war, that Sierra Leone became listed as one of the world's poorest countries. Sierra Leone suffers from many environmental problems such as loss of biodiversity, air pollution and water pollution, which pose a serious hindrance to its economic development. Forna's narrative representations are likewise evocative of Elizabeth DeLoughrey's argument in her book Allegories of the Anthropocene (2019), that in an era characterized by environmental crises, one cannot afford to overlook the narratives based on countries of the Global South [in this case, the tropical Sierra Leone] which are mostly at the forefront of devastating ecological damage (p. 2). Both Ancestor Stones and The Memory of Love fictionalize and focus on the uncontrolled mining and cultivation activities which vastly contributed to the large-scale destruction of the forests, arable 
eTropic 20.2 (2021) Special Issue: Tropical Imaginaries and Climate Crisis

land, river beds, and other water resources. The novels point to the fact that war and industrialization perpetrate slow violence and push the Earth into a "less biologically diverse, less forested, much warmer, and probably wetter and stormier state" (Steffen et al., 2007, p. 614). This slow violence wounds the psyche and the morale of Sierra Leoneans. Their trauma can be understood with reference to Cathy Caruth's argument that trauma "is always the story of a wound that cries out, that addresses us in the attempt to tell us of a reality or truth that is not otherwise available" (1996, p. 4). Here, the focus on human trauma cannot be considered a deliberate departure from environmental trauma, but rather, the interconnectedness of both forms of trauma. Climate trauma draws one's attention to pre-traumatic stress disorder with its anxious visualisation of the environmental predicament that lies ahead due to massive mining, drug cultivation and abuse. Climate crisis is also closely associated and synonymous with racial oppression in Africa as it refers to the control and exploitation of humans and nature by colonisers and further into postcolonial and neocolonial political arenas of control.

Forna's novels give us a picture of West Africa, and Sierra Leone particularly, where during and after the civil war more than half of the population were traumatised, addicted to drugs, and unaware of the destruction of the environment they were contributing to through unrestricted diamond mining and extensive cannabis cultivation. According to the National Drug Law Enforcement Agency Research Report, "Sierra Leone is currently the highest exporter of Marijuana to the neighbouring countries" (WADPN 2017).

In Forma's novels what often seems inexpressible is articulated through language that is emotive and evocative. At one point in The Memory of Love the narrative reflects the resilience and numbness brought about by psychological trauma. There is a pervasive feeling of hopelessness. The story tells us that

In this country there is no dawn. No spring or autumn. Nature is an abrupt timekeeper. About daybreak there is nothing in the least ambiguous, it is dark or it is light, with barely a sliver in between.... The air is heavy and carries the faint odour of mould, like a cricket pavilion entered for the first time in the season. It is always there, stronger in the morning and on some days more than others. It pervades everything, the bed sheets, towels, his clothes. Dust and mould. (2010, p. 27)

The feeling of distress is reinforced by Elias Cole's daughter Mamakay as she says, "Sometimes I think this country is like a garden. Only it is a garden where somebody has pulled out all the flowers and trees and the birds and insects have all left, 
eTropic 20.2 (2021) Special Issue: Tropical Imaginaries and Climate Crisis

everything of beauty. Instead the weeds and poisonous plants have taken over" ( $p$. 351). Here the psychological distress is further amplified by an eco-anxiety - a form of anxiety which often remains unaddressed as the impact of injury to the environment lacks immediacy. In a similar example, Adrian comes across a lush green lawn that he wants to walk on to enjoy the pleasant feeling of soft cool grass under his feet. But he realizes that it is an illusion and the "grass here is spiky, and sharp. Walking across it would be like walking on hot coals" (2010, p. 78). This is suggestive of how the flora in this part of Sierra Leone has changed and how this realization induces anxiety in Adrian. At the same time, it is noticeable that Forna's characters, as espoused by their descriptions of changes in nature - evade the full trauma of a future imaginary of climate crisis.

Expanding upon Caruth's theory of trauma, we draw on the work of Lisa Van Susteren, a psychiatrist specialising in the psychological effects of climate change. She analyses that "much of traumatic stress disorder is how we imagine things are going to be...we have in our minds images of the future that reflect what scientists are telling us; images of people and animals suffering because of dumb choices we're making today" (quoted in Craps, 2020, p. 277). This is the predicament instigated by those Sierra Leoneans who emulated the vices of the whites and wanted immediate economic gain at the cost of their land and water, creating not only civil war, but at the same time causing ecocide.

\section{Towards Reconnecting}

Forna's novels showcase the wrong choices nations and people make. The fight for resources should not take place at the cost of environmental ethics. The fact that we are living in an era of climate emergency calls for renewed responses and reconciliation between humans and nature, and to acknowledge that people suffer from eco-anxiety as a result of climate change.

In this context, Zhiwa Woodbury's article, "Climate Trauma: Toward a New Taxonomy of Trauma" (2019), which broadens the scope of climate trauma to include social trauma, is pertinent. Woodbury contends that:

Accepting the proposition that Climate Trauma is triggering these cultural traumas, bringing them to the surface in ways that demand reconciliation, we begin to see these movements not as distractions from the work we have to do on the climate front but rather as necessary components of a broader social upheaval that is removing the psychological barriers to effectively addressing the climate crisis. Similarly, by bringing increased awareness to the role Climate Trauma 
eTropic 20.2 (2021) Special Issue: Tropical Imaginaries and Climate Crisis

is playing in this social upheaval, reconciliation of cultural traumas is seen as a moral imperative. The oppressed supermajority can then begin to appreciate the broad, systemic changes that must accompany reconciliation of our relationship with the natural world. ( $p$. 7)

Today, climate crisis is a cognitive reality. Understanding the repercussions of ecocide is of utmost importance. And the interconnections of war and the devastation of the physical environment find expression in a growing body of literature of this century that addresses the effects of war on the environment. Considering war as an anthropogenic agent of change because of its widespread destruction over large areas is extremely important in a world characterised by geopolitical conflicts. Everywhere in the world, the magnitude of anthropogenic disturbance by war is significantly high in comparison to other factors. As seen in the case of Sierra Leone, the prolonged duration of the country's civil war exacerbates the environmental catastrophe. Aminatta Forna's Ancestor Stones and The Memory of Love give fictional representations of the long-drawn-out conflict in Sierra Leone, whereby the direct and indirect traumatic impact of the civil war and its aftermath become more poignant.

Trauma rests in the effects of remembrance and revisitation. Through multiple characters' voices and shifting timelines, the two novels by Forna deal with the trauma of war including military-induced destruction of the environment and displacement of people from their natural habitats. Various events in the narratives highlight the role of war as an anthropogenic agent of change that results in the widespread destruction of a nation's ecology. The novels also hint of - but the characters avoid articulation of the threat of impending extinction that overwhelms us and which induces climate trauma or eco-anxiety. And this looming sense of climate trauma simultaneously involves repression of the feelings of anxiety it engenders. In the face of the pending distress that will obviously happen in the future, the human psyche adopts a defence mechanism by trying to dissociate itself from the anxiety that results from climate change (Cherry, 2021). It is important to understand the ramifications that follow repression of climate trauma which will one day affect the entire human race.

Forna shows that the prolonged duration of war induces climate change in its wake and the magnitude of anthropogenic disturbance by warfare is significantly high because the natural environment is valued only instrumentally, solely for human utility, and its destruction justified as a military necessity - as evidenced in military strategies such as scorching the earth, extractive mining or polluting freshwater, etc. This is the bane of the Anthropocene and it calls for a radical and imaginative rethinking of the relationship between humans and nature as a way of preventing ecocide and moving towards a positive ecosophy for sustainability. Forna believes that indigenous stories 
eTropic 20.2 (2021) Special Issue: Tropical Imaginaries and Climate Crisis

about families and ancestors, about the trees, animals, and rocks, about stars and planets and gods, can help us find and remember our place and anchor us in time and space. We, as humans, have a fundamental need for nature. Instead of trying to tame or eliminate or ignore it, it is time we learn to grow with nature. We need to take an active role in celebrating it, and caring for it; thereby nurturing our own needs in the process. Forna insists throughout her novels that only by taking responsibility for the Earth can we truly reconnect with it and with ourselves. 
eTropic 20.2 (2021) Special Issue: Tropical Imaginaries and Climate Crisis

\section{References}

Armstrong, J. (2019). Gothic Resistances: Flesh, Bones, Ghosts and Time in Vietnamese Postwar Fiction. eTropic: Electronic Journal of Studies in the Tropics, 18(1), 28-49. https://doi.org/10.25120/etropic.18.1.2019.3686

Babbit, S. E. (2005). Stories from the South: A Question of Logic. Hypatia 20(3), 1-21. https://doi.org/10.1111/j.1527-2001.2005.tb00484.x

Bielby, K. (2021, May 24). Natural Resources Exploitation and 'Jihadist Drugs' Fueling Terrorist Groups. Homeland Security Today. https://www.hstoday.us/subject-matterareas/counterterrorism/natural-resources-exploitation-and-jihadist-drugs-fuelingterrorist-groups/

Bøås, M., Hatløy, A., \&Bjørkhaug, I. (2009). Alcohol and drugs in post-war Sierra Leone. African Journal of Drug and Alcohol Studies, 7(1). https://doi.org/10.4314/ajdas.v7i1.46358

Caldwell, G. (2011, May 25). Coming Out of the Closet: My Climate Trauma (and Yours?). HuffPost. https://www.huffpost.com/entry/coming-out-of-the-closet b 195770

Caruth, C. (1996). Experience: Trauma, Narrative, and History. Johns Hopkins University Press.

Chaudhuri, U., \& Enelow, S. (2014). Theorizing Ecocide: The Theatre of Eco-Cruelty. Research Theatre, Climate Change, and the Ecocide Project, 22-40. https://doi.org/10.1057/9781137396624 2

Cherry, K. (2021, February 15). Common Defense Mechanisms People Use to Cope with Anxiety. Verywell Mind. https://www.verywellmind.com/defense-mechanisms$\underline{2795960}$

Clark, T. (2019). Ecocriticism on the edge: the Anthropocene as a threshold concept. Bloomsbury Academic.

Craps, S. (2020). Climate Trauma. In C. Davis \& H. Meretoja (Eds.), The Routledge Companion to Literature and Trauma (pp. 275-284). Taylor and Francis. https://doi.org/10.4324/9781351025225-25

DeLoughrey, E. M. (2019). Allegories of the Anthropocene. Duke University Press. https://doi.org/10.1215/9781478090021

Forna, A. (2006). Ancestor Stones. Bloomsbury Paperbacks.

Forna, A. (2010). The Memory of Love. Bloomsbury Publishing.

Gaard, G. \& Gruen, L. (1993) Ecofeminism: Toward Global Justice and Planetary Health. Society and Nature, 2, 1-35.

Hay, A. (2013, April 3). The Origins of Ecocide. Seeing the Woods. https://seeingthewoods.org/2013/04/03/the-origins-of-ecocide/

Helmer, J. (2019) The Environmental Downside of Cannabis Cultivation: Wide-scale cannabis cultivation is causing environmental damage. Federal regulations could change this. June 18, 2019. https://daily.jstor.org/the-environmental-downside-of-cannabiscultivation/

Herman, J. L. (1992). Trauma and Recovery: The Aftermath of Violence - From Domestic Abuse to Political Terror. BasicBooks.

whatnow727.files.wordpress.com/2018/04/herman_trauma-and-recovery.pdf

Hough, P. (2016). Trying to End the War on the World: The Campaign to Proscribe Military Ecocide. Global Security: Health, Science and Policy, 1(1), 10-22. https://doi.org/10.1080/23779497.2016.1208055

Hupy, J. (2008). The Environmental Footprint of War. Environment and History, 14(3), 405421. https://doi.org/10.3197/096734008x333581 
eTropic 20.2 (2021) Special Issue: Tropical Imaginaries and Climate Crisis

Ithaca College. (2017, October 31). Marijuana farming hurts environment, new study finds. ScienceDaily. Retrieved May 30, 2021 from www.sciencedaily.com/releases/2017/10/171031202705.htm

Johnson, C. (17 February, 2010) Sierra Leone farmers turning to cannabis growing:VP. https://www.reuters.com/article/ozatp-leone-drugs-20100217idAFJOE61G0O020100217

Kainulainen, M. (2013). Saying Climate Change: Ethics of the Sublime and the Problem of Representation. symploke 21(1), 109-123. https://doi.org/10.5250/symploke.21.12.0109

Nayar, P. K. (2019). Ecoprecarity: Vulnerable Lives in Literature and Culture. Routledge. https://doi.org/10.4324/9780429294815

Nixon, R. (2011). Slow Violence and the Environmentalism of the Poor. Cambridge, Massachusetts; London, England: Harvard University Press. https://doi.org/10.4159/harvard.9780674061194

Steffen, W., Crutzen, P. J., \& McNeill, J. R. (2007). The Anthropocene: Are Humans Now Overwhelming the Great Forces of Nature. AMBIO: A Journal of the Human Environment, 36(8), 614-621. https://doi.org/10.1579/00447447(2007)36[614:taahno]2.0.co;2

Summers, H.M., Sproul, E. \& Quinn, J.C. (2021). The greenhouse gas emissions of indoor cannabis production in the United States. Nature Sustainability, 4, 644-650. https://doi.org/10.1038/s41893-021-00691-w

Third United Nations Conference on The Least Developed Countries. (2001). Presentation of the Government of Sierra Leone. https://unctad.org/system/files/officialdocument/aconf191cp42sil.en.pdf

UNEP. (2008). Africa: Atlas of Our Changing Environment. UNEP.

UNEP. (2010) Sierra Leone, Environment, Conflict and Peacebuilding Assessesment. Technical Report. February. www.unep.org/conflictsanddisasters

Wang, I. J., Brenner, J. C., \& Butsic, V. (2017). Cannabis, an emerging agricultural crop, leads to deforestation and fragmentation. Frontiers in Ecology and the Environment, 15(9), 495-501. https://doi.org/10.1002/fee.1634

Wartenberg, et al., (2021). Cannabis and the Environment: What Science Tells Us and What We Still Need to Know. Environmental Science \& Technology Letters, 8(2), 98-107. https://doi.org/10.1021/acs.estlett.0c00844

West Africa Drug Policy Network (WADPN). (2017, February 2). Cannabis legalisation in Sierra Leone, What Hope? International Drug Policy Consortium. https://idpc.net/alerts/2017/02/cannabis-legalisation-in-sierra-leone-what-hope.

Woodbury, Z. (2019). Climate Trauma: Toward a New Taxonomy of Trauma. Ecopsychology, 11(1), 1-8. https://doi.org/10.1089/eco.2018.0021

Zalasiewicz, J. A. (2009). The Earth after Us: What Legacy Will Humans Leave in Rocks? Oxford University Press. https://doi.org/10.1093/oso/9780199214976.001.0001

Zierler, D. (2011). The Invention of Ecocide. University of Georgia Press. 
eTropic 20.2 (2021) Special Issue: Tropical Imaginaries and Climate Crisis

Dr Shruti Das is Associate Professor and Head of the Department of English and the Associate Director of the Centre for Canadian Studies, Berhampur University, India. She recently won the Prestigious ASLE Biennial Travel Award for 2019. She has written the Foreword for Crisis of Imagination, a book on Ecocriticism, published by the University of Rzeszow, Poland. She has published 11 books and over 60 research articles and creative works in National and International Journals. Her special interests are Critical Theory, Eco-criticism, South Asian Feminism, Postcolonialism, Indian Literature and Aesthetics, Linguistics and ELT.

Dr Deepshikha Routray is a Lecturer of English at Maharishi College of Natural Law, Bhubaneswar, Odisha, India. She has presented papers at various National and International conferences. She has published research papers in reputed journals and compleed her PhD at Berhampur University. Her research interests include Trauma Literature, Cognitive psychology and Indian classical literature. She is also the Associate Editor of Literary Oracle, a peer-reviewed journal. 